BBA 35886

\title{
THE ROLE OF PROTEIN CARBOXYL GROUPS IN CARBOHYDRATE-CONCANAVALIN A INTERACTION
}

\author{
G. S. HASSING, I. J. GOLDSTEIN AND M. MARINI
}

Department of Biological Chemistry. The University of Michigan, Ann Arbor, Mich. 48104 and Department of Biochemistry, Northwestern University Medical School, Chicago, Ill. 606II (U.S.A.)

(Received February 22nd, 197I)

SUMMARY

I. The role of carboxyl groups in the binding of specific carbohydrates to concanavalin $\mathrm{A}$, the phytohemagglutinin of the jack bean, has been studied using two techniques: (I) $\mathrm{H}^{+}$titration in the presence and absence of methyl $\alpha$-D-mannopyranoside, a specifically bound carbohydrate ligand and (2) chemical modification of the protein carboxyl groups employing glycine methyl ester and a water-soluble carbodiimide, in the presence and absence of the mannoside.

2. It is shown that protein carboxyl groups are masked when concanavalin A is titrated in the presence of the sugar hapten and that this sugar glycoside also protects protein carboxyl groups from modification with glycine methyl ester.

\section{INTRODUCTION}

One of the primary goals of our current investigations of the hemagglutinin of the jack bean, concanavalin $A$, is to elucidate the amino acyl residues that are directly involved in the binding of specific carbohydrates to this protein. Detailed information ${ }^{1-4}$ concerning the specificity of the protein binding sites toward specific carbohydrate substrates indicates that $a$-D-mannopyranosyl residues possess the configurational features which are most complementary to the binding sites of concanavalin A.

Concanavalin A interacts to form an insoluble precipitate with specific polysaccharides and glycoproteins ${ }^{5-18}$ in a manner analogous to antipolysaccharide antibodies interacting with specific polysaccharide antigens. In fact, the concanavalin A system has been proposed as a model for antibody-antigen interaction ${ }^{7,10,19}$. Indeed, this interaction may serve as a general model for protein-carbohydrate interaction.

In a previous report we demonstrated that acetylation of the free amino groups and available phenolic hydroxyl groups had little effect upon the interaction of

Abbreviations: EDC, I-ethyl-3-(3-diethylaminopropyl)carbodiimide hydrochloride; GME, glycine methyl ester.

Biochim. Biophys. Acta, 243 (I97I) 90-97 
concanavalin A with a variety of substrates ${ }^{20}$, thus indicating that these amino acyl residues are probably not of primary importance for saccharide-concanavalin A interaction. We have also reported minimal direct perturbation of tyrosyl or tryptophanyl residues of concanavalin A by saccharide substrates as measured by ultraviolet difference spectroscopy ${ }^{21}$. We now wish to describe the participation of free carboxyl groups of concanavalin A in the interactions of this protein with saccharides. A preliminary account of these results has already appeared ${ }^{22}$.

\section{MATERIALS AND METHODS}

Concanavalin A was prepared as described previously ${ }^{23}$ and was stored in $\mathbf{I . 0} \mathrm{M}$ $\mathrm{NaCl}$ or $0.5 \mathrm{M} \mathrm{KCl}$ at $4^{\circ}$. The ability of the protein to interact with polysaccharide (dextran B-I355-S) was assayed by the quantitative precipitin technique ${ }^{\mathbf{1 0}}$ or by a turbidimetric procedure ${ }^{20}$. All carbohydrates used were chromatographically pure.

\section{Modification of carboxyl groups}

Preparation of $\left[{ }^{14} C\right]$ glycine methyl ester $\left(\left[{ }^{[14} C\right] G M E\right)$. O.I $\mathrm{mC}$ of $\left[\mathrm{I}^{14} \mathrm{C}\right]$ glycine (New England Nuclear, Boston, Mass.) was diluted with $7.5 \mathrm{~g}$ glycine (Eastman Organic Chemicals, Rochester, N.Y.) and refluxed for $7 \mathrm{~h}$ in $300 \mathrm{ml}$ of methanolic $\mathrm{HCl}$ (approx. $15 \% \mathrm{HCl}(\mathrm{w} / \mathrm{v}))$. The reaction mixture was cooled and concentrated in vacuo at $40^{\circ}, \mathrm{HCl}$ being removed by several evaporations with methanol. The crude crystals (I2.5 g, 99\%) had m.p. I68-I70 . Recrystallization from methanol gave white needles, m.p. $176.5-177^{\circ}(9.4 \mathrm{~g}, 75 \%)$. The specific activity of the $\left.{ }^{[14} \mathrm{C}\right] \mathrm{GME}$ was determined to be $2.50 \cdot \mathrm{IO}^{6}$ disint./min per mmole.

Counting procedure. All radioactive counting was done using a dioxane-based scintillation fluid which had the following composition: $0.050 \mathrm{~g} \mathrm{I,4-bis-[2-(5-phenyl-}$ oxazole)]benzene (New England Nuclear Corp., Boston, Mass.), 6.0 g 2,5-diphenyloxazole (New England Nuclear Corp., Boston, Mass.), and 50.o g naphthalene (Eastman Organic Chemicals, Rochester, N.Y.) were dissolved in dioxane (A.R., Eastman Organic Chemicals, Rochester, N.Y.) to a final volume of I.o l. Each sample ( $\leq$ I.o ml, containing $\leq 0.2 \mathrm{M} \mathrm{NaCl}$ ) was added to scintillation vials containing $15 \mathrm{ml}$ scintillation fluid and approx. 6o mg of "Cab-O-Sil" (Packard Instrument Co., Downers Grove, Ill.) as a suspending agent, shaken well, and counted in a Packard Tri-Carb Scintillation Counter Model 2009 (Packard Instrument Co., Downers Grove, Ill.) at ambient temperature. In order to determine counting efficiency, an internal standard of $0.050 \mathrm{ml}\left[{ }^{14} \mathrm{C}\right]$ toluene (New England Nuclear Corp., Boston, Mass.) containing 26300 disint./min was added and the sample was recounted. Counting efficiencies in this system were determined to be $75-80 \%$.

Modification of carboxyl groups. Parallel reactions were performed on concanavalin $\mathrm{A}$ in the presence and absence of methyl $\boldsymbol{\alpha}$-D-mannopyranoside, following the general procedure of HoARE AND KOSHLAND ${ }^{24}$. Optimal conditions and procedures were as follows: to a rapidly stirred solution of concanavalin $\mathrm{A}(9-\mathrm{I} 4 \mathrm{mg} / \mathrm{ml})$ in $1.0 \mathrm{M}$ $\mathrm{NaCl}$ and containing GME, adjusted to the appropriate $\mathrm{pH}$ with $2.0 \mathrm{M} \mathrm{NaOH}$, was added sufficient 0.4 M I-ethyl-3-(3-dimethylaminopropyl)carbodiimide hydrochloride (EDC) (Ott Chemical Co., Muskegon, Mich.) such that the final concentrations of GME and EDC were $0.25 \mathrm{M}$ and $0.025 \mathrm{M}$, respectively. The reaction consumed small amounts of acid initially and the $\mathrm{pH}$ was maintained with a Radiometer TTT-lc 
Titrator connected to a Radiometer Titrigraph SBR-2c (Radiometer, Copenhagen, Denmark) using o.I $\mathrm{M} \mathrm{HCl}$. Aliquots (approx. I $\mathrm{ml}$ ) were periodically withdrawn with a syringe and plunged into $2.0 \mathrm{ml}$ of $\mathrm{r} .0 \mathrm{M}$ acetate buffer $(\mathrm{pH} 4.75)$. This procedure effectively quenched the reaction by swamping the system with a large excess of carboxyl groups. The samples were dialyzed exhaustively against $0.2 \mathrm{M} \mathrm{NaCl}$ to a final constant level of radioactivity. Subsequently, each sample was clarified by centrifugation and its concentration (nitrogen analysis) ${ }^{10}$ and activity determined (ability to precipitate with specific polysaccharides) ${ }^{2}$. The radioactive disint./min were determined per mg protein and related to moles GME bound per I00 $000 \mathrm{~g}$ concanavalin $\mathrm{A}$, which was assumed to be identical to the number of carboxyl groups modified by GME.

To assess the possibility that tyrosyl residues ${ }^{25}$ may also have reacted with GME, several highly modified concanavalin A samples were examined further. It was found that $\varepsilon_{M}$ at $280 \mathrm{~m} \mu$ was identical to the native protein and that the radioactivity (disint./min per $\mathrm{mg}$ ) of concanavalin $\mathrm{A}$ was unaffected by treatment with hydroxylamine at neutral $\mathrm{pH}$.

\section{pH titrations}

A solution of concanavalin A $(8.80 \mathrm{mg} / \mathrm{ml})$, which had been exhaustively dialyzed against $0.5 \mathrm{M} \mathrm{KCl}$, was titrated with I.oo $\mathrm{M} \mathrm{KOH}$ and 1 .oo $\mathrm{M} \mathrm{HCl}$ using the apparatus of MARINI AND WUNSCH${ }^{26}$. Titrations were performed as follows: a solution of concanavalin $\mathrm{A}(7.0 \mathrm{ml})$ was placed in the titration vessel and to it was added $1.0 \mathrm{ml}$ water or $1.0 \mathrm{ml}$ of a solution of sugar (final sugar concentration was o. I M). At this point the $\mathrm{pH}$ of the solution was generally about 5.45. This solution, at $20^{\circ}$, was titrated downscale with $\mathrm{HCl}$ to $\mathrm{pH} 2.00$ followed by titration upscale with $\mathrm{KOH}$, usually to $\mathrm{pH}$ I2.0.

\section{RESULTS}

\section{Modification of carboxyl groups}

Preliminary experiments showed that concanavalin $\mathrm{A}$ rapidly lost activity when treated with GME and $\mathrm{EDC}$ at $\mathrm{pH}$ 4.75. The results of a typical experiment are presented in Fig. I. There is only a slight difference in the loss of activity of concanavalin A between the reactions carried out in the presence ("protected") and absence ("unprotected") of methyl $\alpha$-D-mannopyranoside, but there is almost no difference in the absolute extent of modification (Table I). Fig. 2 shows the quantitative precipitation assay for the 5 -min and 20 -min reaction time samples; there are small differences in reactivity.

In an examination of the effect of $\mathrm{pH}$ on the extent of carboxyl group modification and on the ability of methyl $\alpha$-D-mannopyranoside to protect concanavalin $A$ it was observed that $\mathrm{pH} 5.75$ was the most suitable. The results obtained at this $\mathrm{pH}$ are shown in Fig. 3 and the extent of modification of the protein is presented in Table II. It is evident that methyl $\alpha$-D-mannopyranoside protects concanavalin A from activity loss and from modification of some of its carboxyl groups. Note also that the overall extent of modification is less at $\mathrm{pH} 5.75$ than at $\mathrm{pH} 4.75$. Methyl $\alpha$-D-galactopyranoside (a non-binding sugar ligand) did not protect concanavalin A against modification with GME and there is no observable difference in activity loss 

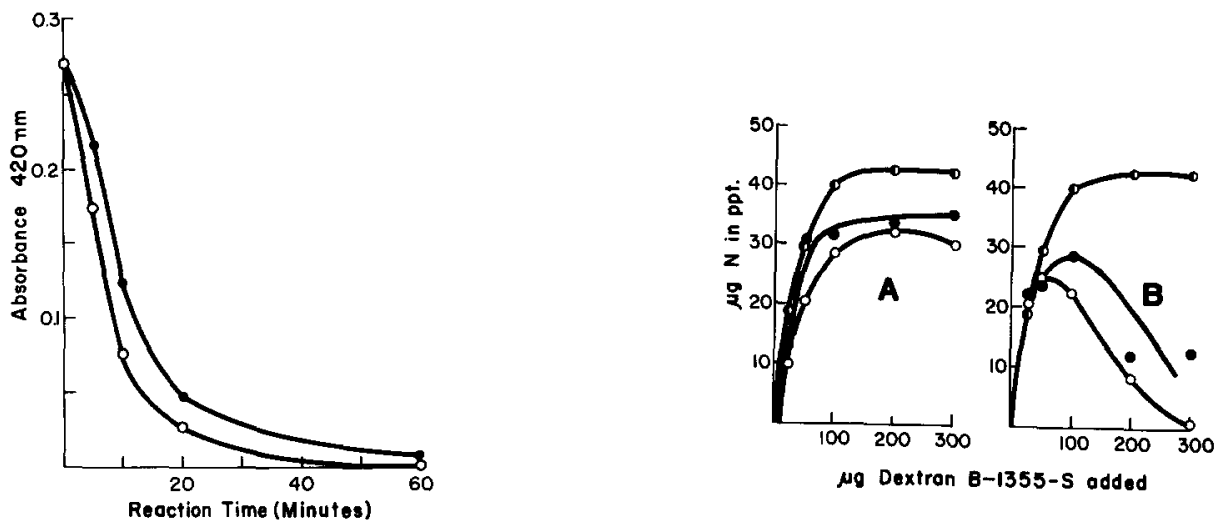

Fig. I. Activity measurements of concanavalin A after treatment of the protein with GME for various time periods. Protein $(60 \mathrm{mg})$ was reacted with $0.25 \mathrm{M} \mathrm{GME}$ and $0.025 \mathrm{M} \mathrm{EDC} \mathrm{at} \mathrm{pH} 4.75$ as described in the experimental section. Final volume was $6.4 \mathrm{ml}$. $\bigcirc-0$, unprotected reaction; - protected reaction, run in the presence of $0.1 \mathrm{M}$ methyl $\alpha$-D-mannopyranoside.

Fig. 2. Quantitative precipitation curves of dextran B-I355-S with native and GME-modified concanavalin A. All incubations contained $4^{6} \mu \mathrm{g}$ concanavalin A nitrogen. Reaction with GME carried out as in Fig. I. A. Reaction time with GME $5 \mathrm{~min}$. B. Reaction time with GME $20 \mathrm{~min}$. $\mathrm{O}-\mathrm{O}$, unprotected reaction; - protected reaction, run in the presence of o. $\mathrm{M}$ methyl $a$-D-mannopyranoside; $\Theta \Theta$, control (native, untreated concanavalin A).

\section{TABLE I}

Extent of modification of concanavalin A by GME and EDC at pH 4.75

Experimental conditions given in Fig. I.

\begin{tabular}{lll}
\hline $\begin{array}{l}\text { Time } \\
\text { (min) }\end{array}$ & \multicolumn{2}{c}{ Moles GME bound per Ioo ooo g concanavalin $A$} \\
\cline { 2 - 3 } & Protected reaction & Unprotected reaction \\
\hline & & \\
5 & 7.8 & 8.2 \\
10 & I 5.8 & I 5.6 \\
20 & 24.6 & 25.9 \\
60 & 40.2 & $4 \mathrm{I} .7$ \\
\hline
\end{tabular}

as compared to the control. Quantitative precipitation analyses of the 5 -min and $60-$ min samples shown in Fig. 2 are given in Fig. 4. After a reaction time of 5 min there are only slight differences in activity between protected and unprotected samples. However, the 6o-min aliquots show marked differences in reactivity with dextran. Almost twice as much of the protected protein precipitates with dextran B-I355-S as compared to the unprotected sample. Fig. 5 demonstrates the timecourse of modification in this experiment in both the protected and unprotected reaction. In the unprotected reaction, not only is the final extent of modification greater, but the initial rate of modification is also greater.

\section{pH titrations}

Fig. 6 shows the titration curves obtained when concanavalin A was titrated in the presence and absence of methyl $\alpha$-D-mannopyranoside (a good binding ligand) and methyl $a$-D-galactopyranoside (a non-binding ligand). The titrations performed 

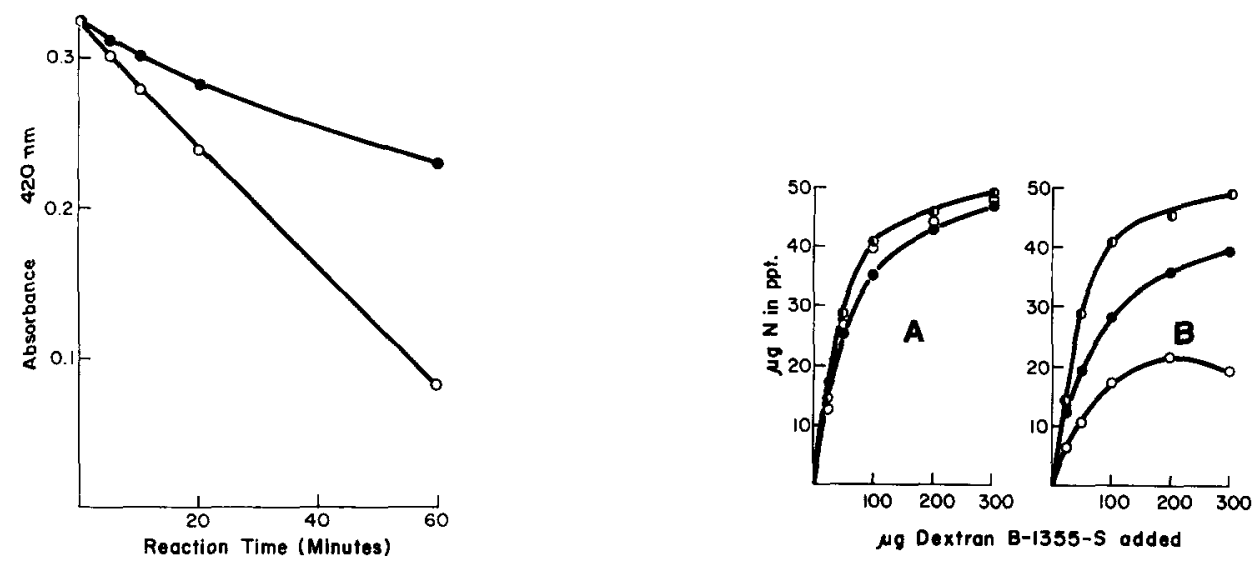

Fig. 3. Activity measurements of concanavalin A after reaction of the protein with GME for various time intervals. Protein $(60 \mathrm{mg}$ ) was treated with $0.25 \mathrm{M} \mathrm{GME}$ and $0.025 \mathrm{M} \mathrm{EDC} \mathrm{at} \mathrm{pH} \mathrm{5.75.}$ Final volume was $4.3 \mathrm{ml}$. $\mathrm{O}-\mathrm{O}$, unprotected reaction; - protected reaction run in the presence of o.I M methyl $a$-D-mannopyranoside.

Fig. 4. Quantitative precipitation curves of native and GME-modified concanavalin A with dextran B-I355-S. All incubation mixtures contained $50 \mu \mathrm{g}$ concanavalin A nitrogen. Concanavalin A was reacted with $0.25 \mathrm{M} \mathrm{GME}$ and $0.025 \mathrm{M} \mathrm{EDC}$ at $\mathrm{pH} 5.75$ for $5 \mathrm{~min}$ (A) and for $60 \mathrm{~min}$ (B). $\mathrm{O}-\mathrm{O}$, unprotected reaction; - - , protected reaction run in the presence of $0 . \mathbf{M}$ methyl $\alpha$-D-mannopyranoside; $\mathbf{D}-\mathbf{D}$, control (native, untreated concanavalin A).

\section{TABLE II}

EXTENT OF MODIFICATION OF CONCANAVALIN A BY GME AND EDC AT pH 5.75

Experimental conditions given in Fig. 3 .

\begin{tabular}{lll}
\multirow{2}{*}{$\begin{array}{l}\text { Time } \\
\text { min) }\end{array}$} & \multicolumn{2}{c}{ Moles GME bound per Ioo ooo g concanavalin A } \\
\cline { 2 - 3 } & Protected reaction & Unprotected reaction \\
\hline & & 2.0 \\
5 & 0.4 & 4.0 \\
20 & 1.7 & 9.6 \\
60 & 4.4 & 25.9
\end{tabular}

in the presence or absence of the galactoside are identical whereas in the presence of methyl $\boldsymbol{\alpha}$-D-mannopyranoside fewer equivalents of acid are consumed between $\mathrm{pH} 5.5$ and 2.0 (titrating downscale) and fewer equivalents of base are consumed between $\mathrm{pH} 2.0$ and 5.5 (titrating back, upscale). Above $\mathrm{pH} 5.5$ the titrations are parallel and identical. That this is indeed the case is shown in Fig. 7, in which the two curves of Fig. 6 are subtracted. In the presence of methyl $\alpha$-D-mannopyranoside, eight fewer equivalents of acid (titrating downscale) and base (titrating upscale) per 100 ooo $\mathrm{g}$ of concanavalin $\mathrm{A}$ are consumed between $\mathrm{pH} 2.0$ and $\mathrm{pH}$ 5.5. The difference curve (Fig. 7) may be interpreted as the loss of eight groups with $\mathrm{p} K$ approx. 3.8 which would correspond to the ionizations of carboxyl groups in proteins ${ }^{27}$. 

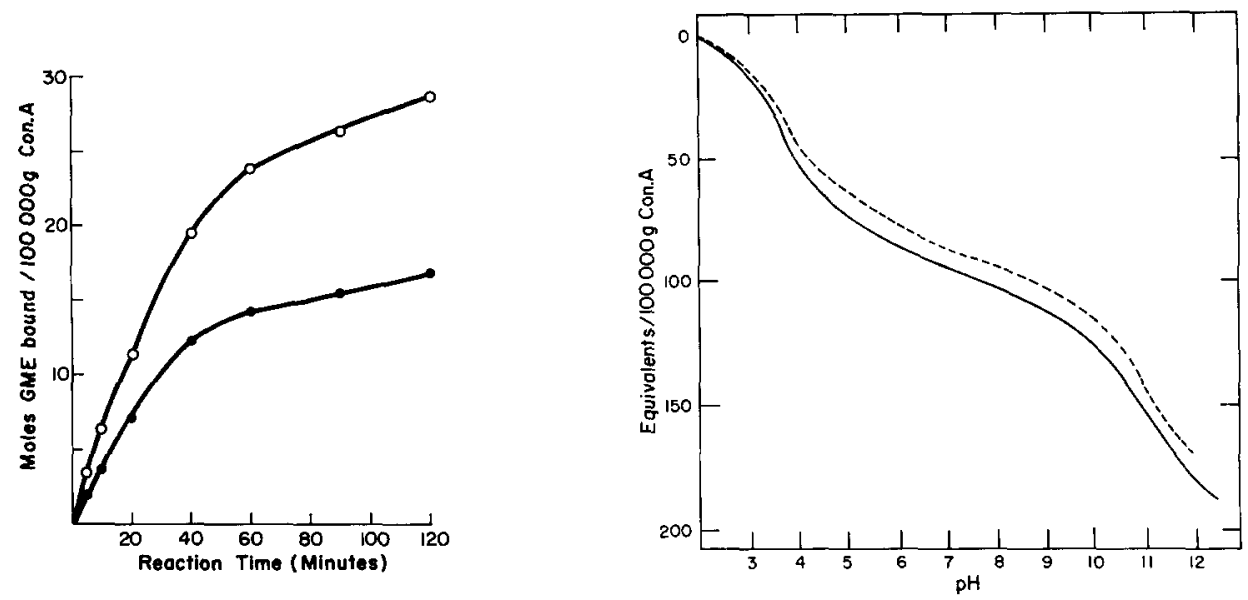

Fig. 5. Extent of modification of concanavalin A by GME and EDC, pH 5.75 as a function of reaction time. Reaction conditions are given in Fig. 3. O-O, unprotected reaction; - , protected reaction run in the presence of o. I M methyl $\alpha$-D-mannopyranoside.

Fig. 6. $\mathrm{pH}$ titration curves of concanavalin A. See MATERIALS AND METHODS for conditions of titrations. - - titration of concanavalin $\mathrm{A}$ in the absence and presence of methyl $\alpha$-D-galactopyranoside; ---.-.--, titration of concanavalin $\mathrm{A}$ in the presence of o. I M methyl $\alpha$-D-mannopyranoside.

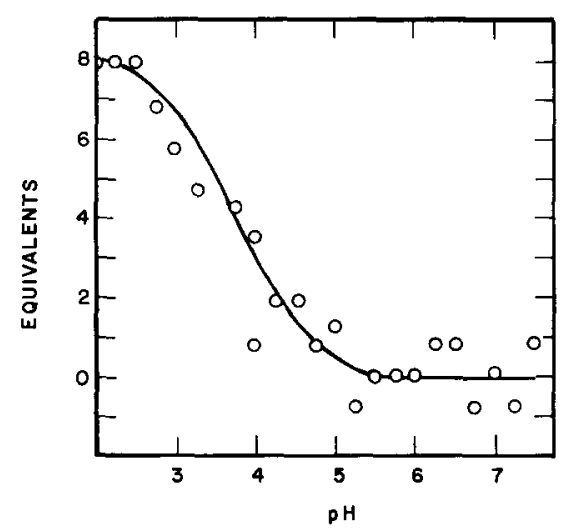

Fig. 7. pH difference curves as prepared from Fig. 6.

\section{DISCUSSION}

In a previous communication ${ }^{21}$ we reported that despite the failure of concanavalin A to precipitate with certain specific branched polysaccharides at low $\mathrm{pH}$ values (e.g. $\mathrm{pH} 2.4$ ), this protein still retained the capacity to bind specific low molecular weight glycosides and polysaccharides. Thus, using the technique of ultraviolet difference spectroscopy, it was shown that $p$-nitrophenyl $\alpha$-D-manno- and $a$-D-glucopyranoside interact specifically with concanavalin A over a broad $\mathrm{pH}$ range ( $\mathrm{pH} 3-8)$ with considerable interaction even at $\mathrm{pH} \mathrm{2.4}$. Furthermore, a yeast mannan was also shown to interact in the same manner with the protein at $\mathrm{pH} 2.4$ 
although the mannan did not precipitate with concanavalin $A$ as is customary at pH 5-7. Biogel column chromatography and sedimentation velocity experiments with the ultracentrifuge demonstrated that concanavalin A did not undergo a molecular weight change at $\mathrm{pH} 2.4$ (ref. $2 \mathrm{I}$ ).

In view of the low $\mathrm{pH}$ values at which concanavalin A still retains the capacity to bind carbohydrates, it is of interest that chemical modification and $\mathrm{pH}$ titration studies on this protein both strongly implicate the importance of free carboxyl groups in the binding phenomenon. Titration studies indicate that approx. eight carboxyl groups (per $100000 \mathrm{~g}$ ) are not available for titration when the protein is in contact with methyl $\alpha$-D-mannopyranoside (Figs. 6 and 7 ). Titration in the presence of methyl $\alpha$-D-galactopyranoside (a non-binding ligand) was identical to the titration of the native protein, demonstrating that this phenomenon is due to specific interaction of the mannoside with concanavalin A. Thus, titration with acid to $\mathrm{pH} 2.0$ does not appear to disrupt the carbohydrate binding sites (see above) and certain carboxyl groups are not titrated when concanavalin $\mathrm{A}$ is in contact with this glycoside. This change in $\mathrm{p} K$ could be due to direct interaction of side chain carboxyl groups with the mannoside in the binding sites. Alternatively, there may be side chain carboxylate groups which have a locally altered environment due to a conformational change of the protein when concanavalin A binds carbohydrates.

Chemical modification studies confirm the involvement of carboxyl residues in the binding of carbohydrates by concanavalin $\mathrm{A}$. When the studies were performed at $\mathrm{pH} 5.75$, modification of free carboxyl groups by condensation with GME and EDC resulted in loss of concanavalin A activity (Figs. 3-5). However, addition of methyl $\alpha$-D-mannopyranoside to the reaction mixture protected the protein against both activity loss and modification of its carboxyl groups.

Potential side reactions of GME and EDC with other amino acyl side chains (e.g. tyrosyl residues) do not appear to be important as described above. The possible side reaction of EDC with sulfhydryl residues ${ }^{28}$ may be eliminated from consideration since concanavalin A does not contain cysteine $\mathrm{e}^{29,30}$.

There is good evidence for the involvement of carboxyl groups in the binding of saccharides to the active sites of a variety of different classes of proteins. PHILLIPS $^{31}$ and his co-workers for example have implicated carboxyl groups (e.g. Asp IoI and I03) in the interaction of lysozyme with cell wall polysaccharide and competitive inhibitors. In a study of the effect of $\mathrm{pH}$ on a dextran-human antidextran system, Govld et al ${ }^{32}$ showed that the descending portion of the $\mathrm{pH}$ optimum curve titrated between $\mathrm{pH}^{-4} 4$ in the acid region ${ }^{32}$. This could also involve carboxyl groups in the antibody combining sites.

In our studies on the lima bean (Phaseolus lunatus) lectin we have similarly noted what may be the titration of a carboxyl group in the combining site of this phytohemagglutinin ${ }^{33}$. Finally, in studies of the effect of $\mathrm{pH}$ on the labellar sugar receptor of the fleshfly, SHIRAishi AND Morita ${ }^{34}$ show a $\mathrm{pH}$-response curve in which the acid limb of the curve is in the $\mathrm{p} K$ range of a carboxyl group.

\section{ACKNOWLEDGMENT}

This work was supported by Grants AI-IOI7I and AM-IOI7I from the National Institutes of Health. 


\section{REFERENCES}

I I. J. Goldstein, C. E. Hollerman and E. E. Smith, Biochemistry, 4 (1965) 876.

L. L. So And I. J. Goldstein, J. Immunol., 99 (I967) I 58.

E. E. Smith and I. J. Goldstein, Arch. Biochem. Biophys., i2 I (I967) 88.

R. D. Poretz and I. J. Goldstein, Biochemistry, 9 (1970) 2890.

5 J. B. Sumner ans S. F. Howell, J. Immunol., 29 (I935) i i 3.

6 J. A. Cifonelli, R. Montgomery and F. Smith, J.Am. Chem. Soc., 78 (1956) 2485.

7 I. J. Goldstein, C. E. Hollerman and J. M. Merrick, Biochim. Biophys. Acta, 97 (1965) 68.

8 I. J. Goldstein and L. L. So, Arch. Biochem. Biophys., II I (1965) 407.

9 I. J. Goldstein and R. N. IYer, Biochim. Biophys. Acta, I2 I (I966) I97.

Io L. L. So And I. J. Goldstein, J. Biol. Chem., $24^{2}$ (I967) I6I7.

I I L. L. So AND I. J. Goldstein, J. Biol. Chem., 243 (I968) 2003.

12 1. J. Goldstein, R. D. Poretz, L. L. So ANi Y. YanG, Avch. Biochem. Biophys., 127 (I968) 787 .

I 3 K. O. Lloyd, E. A. Kabat and S. Beychok, J. Immunol., IO2 (I969) т354.

I 4 H. Markowitz, J. Immunol., IO3 (I969) 308.

15 S. Nakamura, K. Tanaka and S. MurakaWa, Nature, 188 (1960) I 44.

I6 H. Harris and E. B. Robson, Vox Sang., 8 (1963) 348.

I7 M. A. LEON, Science, $158(1967)$ I 325.

i 8 I. J. Goldstein, L. L. So, Y. Yang ANd Q. C. Callies, J. Immunol., I03 (1969) 695.

ig E. J. Hehre, Bull. Soc. Chim. Biol., 42 (I960) I 58 I.

20 B. B. L. Agrawal, I. J. Goldstein, G. S. Hassing and L. L. So, Biochemistry, 7 (1968) 42 II.

2 I G. S. Hassing And I. J. Goldstein, Eur. J. Biochem., i6 (ig7o) 549.

22 G. S. Hassing, I. J. Goldstein and M. A. Marini, Abstr. $156 t h$ Natl. Meeting Am. Chem. Soc., Atlantic City, N.J., September, r968, 228.

23 B. B. L. Agrawal and I. J. Goldstein, Biochim. Biophys. Acta, I24 (1967) 218.

24 D. G. Hoare and D. E. Koshland, JR., J. Biol. Chem., 242 (I967) 2447.

25 K. L. Carraway aNd D. E. Koshland, JR., Biochim. Biophys. Acta, I6o (Ig68) 272.

26 M. A. Marini and C. Wunsch, Anal. Biochem., 6 (rg63) 534.

27 C. Tanford, Adv. Protein Chem., I 7 (1962) 69.

28 K. L. Karraway and R. B. Triplett, Biochim. Biophys. Acta, zoo (1970) 566.

29 B. B. L. Agrawal and I. J. Goldstein, Biochim. Biophys. Acta, I 33 (1967) 376.

3o M. O. J. Olson AND I. E. Liener, Biochemistry, 6 (1967) Io5.

3 I D. C. Phillips, Proc. Natl. Acad. Sci. U.S., 57 (I967) 484.

32 H. A. Gould, T. J. Gill III and H. W. Kunz, J. Biol. Chem., 239 (I964) 307 I.

33 W. Galbraith and I. J. Goldstein, FEBS Letters, 9 (1970) 197.

34 A. Shiraishi and H. Morita, J. Gen. Physiol., 53 (I969) 450.

Biochim. Biophys. Acta, 243 (1971) 90-97 